\title{
Heterotopic and Holey Spaces as Tents for the Nomad: Rereading Gwen John's Letters
}

Maria Tamboukou, University of East London, UK

\begin{abstract}
In this article I look into the letters and paintings of the expatriate Welsh artist Gwen John, tracing her spatial practices in the urban spaces of modernity. Drawing on Foucault's, Deleuze's and Guattari's analytics, I argue that John's spatial narratives chart heterotopias and holey spaces that challenge the hegemonic spaces of modernity, temporarily giving shelter to what Braidotti has theorized as female nomadic subjects. John's fluid spatiality is thus conceived as an event that interrogates static conceptualizations of spaces and identities and foregrounds difference, movement and forces of desire as constitutive of the real.
\end{abstract}

Keywords: desire; epistolary narratives; nomadic subjects; Gwen John; heterotopias; holey spaces

One dream was strange. I dreamt that we had gone up the Eiffel tower and high up we had found the sea and we got undressed and were swimming, oh we were so happy! But after some time a man cried that the machine was about to go down and we were forced to get dressed. ${ }^{1}$

In this passage from an undated letter Gwen John brings together real and imagined spaces in narrating a dream to her lover, the famous sculptor Auguste Rodin. Her dream narrative about ascending the Eiffel tower to find the sea and happiness at the top, carries traces of the cartography of her spatiality: the sea she loved so much, becomes part of a significant landmark of the Parisian urban landscape, a corner in the world to shelter her love. The narrative unfolds as an entanglement of desiring bodies with real but incompatible spaces - the sea and the tower, nature and culture. In this paper I will focus on entanglements between bodies and spaces drawing on Foucauldian and DeleuzoGuattarian analytics and concepts. The discussion will revolve around the letters and paintings of Gwen John (1876-1939), a Welsh born artist who studied at the Slade School of Art in London but mostly lived and worked in Paris in the first half of the twentieth century. Throughout her life John wrote many letters to her lovers and friends: letters opened up channels of communication for an expatriate artist and a woman passionately in love. These letters have informed a wide range of discourses around the artist through which she emerges as a figure of the interior (Langdale and Jenkins, 1985), a woman who loved being in the room and therefore an exemplary paradigm of the impossibility of the flâneuse (Wolff, 1994). My work with John's epistolary archive ${ }^{2}$ has followed different routes of analysis: what I will argue in this paper is that John's spatial narratives chart heterotopias (Foucault 1988) and holey spaces (Deleuze and Guattari 1988) that challenge the hegemonic spaces of modernity, temporarily giving shelter to female nomadic subjects (Braidotti 1994). John's fluid spatiality is thus conceived as an event that interrogates static conceptualizations of spaces and identities and foregrounds 'difference rather than identity, movement rather than stasis and change rather than what remains the same'. (Lorraine 2005, 159) 
In analyzing John's spatial stories I have drawn on the Leibnizian concept of the fold. Deleuze (1993) has used this concept to trace connections between spaces and bodies: the world folds into the self in different speeds and on a variety of levels and intensities affecting the ways we live, relate to other bodies and make sense of our worldliness. At the same time however, we keep folding out into the world, Foucault in his later work argued, acting upon received knowledges, discourses and practices and thus moulding ourselves as subjects through the deployment of technologies of the self. (1988) Probyn has particularly pointed to the crucial concept of the fold in both Foucault's and Deleuze's analyses, foregrounding the very constitution of subjectivity as an incessant process of folding and unfolding: 'The act of pleating or folding ('la pliure') is thus the doubling-up, the refolding, the bending-onto-itself of the line of the outside in order to constitute the inside/outside - the modes of the self.' $(1993,129)$

In this light, the different spaces and places that John lived in, fold into her body activating a series of movements, practices, thoughts and affects. As she folds out into the world constituting herself as a subject, the spaces that she moves through keep changing with her rather than staying lifeless, static or monolithic. ${ }^{3}$ John is thus continuously surrounded by what Deleuze and Guattari have theorized as striated and smooth spaces. (1988) In their analysis, striated spaces are hierarchical, ruleintensive, strictly bounded and confining - the patriarchal urban spaces of modernity, being very good examples here. But there are always forces of deterritorialization, lines of flight, Deleuze and Guattari argue, that shatter segmentarities and open up smooth spaces that are unmarked, dynamic and create conditions of possibility for transformations to occur. Moreover there is no dualistic opposition in this configuration; as a matter of fact, the world is being experienced as a continuum of striated and smooth spaces: 'smooth space is constantly being translated, transvered into a striated space; striated space is constantly being reversed, returned to a smooth space.' (1988, 474) Deleuze and Guattari have actually written about holey spaces, transient spaces, hanging in the intermezzo of smooth and striated spaces, becoming 'tents for the nomad' $(1988,413)$. There is a conceptual proximity I argue between holey spaces as zones of indeterminacy, 'tents for the nomad' in Deleuze and Guattari's analytics and the notion of heterotopia that Foucault has coined in theorizing the complicated and often contradictory structure of various relational emplacements that constitute the outer space of our living experiences. ${ }^{4}$

As juxtaposed to utopias, or unreal places, heterotopias are configured as spatial entities of heterogeneous elements that are part of the hegemonic spaces, 'but in such a way that they suspend, neutralize, or reverse the set of relations that are designated, reflected, or represented by them.' (Foucault 1998, 177) Given their heterogeneous constitution, heterotopias are ambiguous spaces traversed by antagonistic power relations and saturated by dissonant discourses. Drawing on this pluralistic coexistence of disparate elements Hetherington (1998) has argued that 'heterotopias' are sites of 'alternate ordering' in modernity. Hetherington has particularly highlighted the labile properties of heterotopias, emphasizing process and 'ordering' rather than order. Heterotopia is thus: "not something fixed, but a mobile process full of uncertainty, heterogeneity and contradiction' (1998,7). 
Clearly while there are homologies and correlations between heterotopias and holey spaces, there are also notable differences in their configuration. Heterotopias in Foucault's theorizations are marked by the interplay of power relations and antagonistic discourses: 'a kind of contestation both mythical and real of the space in which we live' $(1998,179)$. While however heterotopias constantly contest the centrality of hegemonic spaces, they do not necessarily become spaces of resistance against domination; they are rather spaces of transition and tension, intrinsically interwoven in the Foucauldian power/resistance complex, the argument that power is actually dependent on resistance: 'where there is power, there is a resistance, and yet, or rather consequently, this resistance is never in a position of exteriority, in relation to power' (Foucault 1990, 95). In Foucault's conceptualization then, while there is no power without resistance, resistance is not necessarily linked to liberation and emancipation, it is rather an effect of the circulation of relations of power. While heterotopias are charted in a complex network of power relations at play, configured as labile spaces of tension, but not necessarily of freedom, holey spaces are tentatively constituted through forces of desire: they open up unexpectedly in the middle of things, the intermezzo, as fleeting spaces of freedom, 'tents for the nomad' (Deleuze and Guattari 1988, 413). Given their ephemeral constitution, holey spaces are thus more difficult to be colonized by dominant discourses and practices: they always emerge in the holes and cracks of hegemonic social and spatial formations; they become 'zones of indeterminacy that bodies-in-becoming may make their own' (Massumi 1993, 104). Emerging in the interstices of dominant structures, holey spaces allow minor tactics to be deployed and create conditions of possibility for open planes that are 'intersitial, they inhabit the in-between of socially significant constellations, they are where bodies in the world but between identities go' (105).

What is therefore highlighted in the multifarious connections between heterotopias, and holey spaces is the recognition that both spaces are liminal sites for nomadic subjects to inhabit and sometimes 'make their own'. What is also significant here is Deleuze's argument that nomadic subjectivities are always constituted within 'the given' $(1991,120)$. We can only have 'a practical subject', not a 'knowing' subject, Deleuze has written; this is as far as we can get in grasping the subject: sketching a map of its nomadic movements. As I will further show in the discussion of the paper, John's letters and paintings offer textual and visual images which chart a cartography of movements within and between spaces that can never be bounded, stabilized or represented; they keep becoming other: heterotopic and holey spaces always entangled with nomadic subjects.

Within this entanglement of bodies and spaces, flows of desire intermingle with antagonistic power relations, while deterritorializations and lines of flight are interrupted and succeeded by reterritorializations and molar lines. In their analyses, Deleuze and Guattari (1988) have used the conceptual pair of the 'molar' and the 'molecular' to refer to different types of political bodies, organizations and forms. Molar entities are well-defined organizations that belong to the State or the civic world - the domestic spaces of modernity in John's case for instance. Molecular forms refer to micropolitics that are at work in the interstices of status apparati and structures, but are not easily perceived. The molar and the molecular should not be conceived as a binary opposition, since there are continuous movements and transpositions in between them: 'every society and every individual, are thus plied by both segmentarities simultaneously: one molar, the other molecular' (Deleuze and 
Guattari 1988, 213). In this context, desire is the moving force between the molar and the molecular: it is not attached to subjects or objects; it connects bodies and constitutes the social and the subject herself. As Probyn has written, 'desire is a method of doing things, of getting places, [...] a mode of connection and communication' $(1996,41)$.

In this context John's letters are expressions, signs of this cycle of folding, unfolding and refolding: as auto/biographical narratives they vividly convey experiences of a young woman's interrelationship with patriarchal relations, the tyranny of heterosexual love, the difficulties of becoming an artist and the paradoxes of inhabiting the urban spaces of modernity. The letters are further rich in terms of the plots they unfold and the narrative tropes they draw on to convey passion and meaning. A narrative approach to spatial analytics however, is inherently limited. As Doreen Massey (2005) has persuasively argued, space-very much like time-is impossible to be pinned down, stabilized and therefore I would add, textually represented. Considering these problems, my analysis is placed within a critical field in narrative research that interrogates certainties about the referentiality of narratives, the possibilities of what they do or can represent. ${ }^{5}$ What I propose is that John's letters do not represent reality, but rather respond to it: her spatial stories and images become interwoven in a complicated matrix of partial truths, discourses and practices of her times and geographies, a grid of what drawing on Foucault (1988) I have called, narrative technologies of the self (Tamboukou, 2010a). By drawing on the Foucauldian concept of self-technologies my argument is that in writing letters John attempts to make sense of the chaotic world surrounding her, constantly reflecting upon her relationship with other beings, both human and non-human. ${ }^{6}$ Her letters constantly problematize and challenge human communication, reflect on the meaning of silences, the joys and shortcomings of friendship, the ineffability of passion, the pleasures of love, the strange affects of human-animal relations. ${ }^{7}$ John's letters should therefore be read as messages for her addressees but also as technologies she constantly deployed to act upon the formation of her subjectivity, participating as Foucault (1988) has shown, in processes of subjectification, actively turning herself into a subject.

In analysing John's epistolary narratives as narrative technologies of the self, entanglements of material practices and discourses, I am obviously not interested in capturing 'the truth' about her life or even recovering her as a historical subject. Following Foucauldian and DeleuzoGuattarian lines, my task is to excavate layers of regimes of truth and trace signs of forces of desire in the stories she recounts in her letters. In this light I see John moving around the vicinities of subject positions - a woman artist, a new woman, a lover, a friend - but I cannot pin her down to any of them. John is not a fully formed pre-existing subject but rather a subject constituted through the material/spatial practices and epistolary discourses that she is entangled with: John-painting/despairing/writing-in her room, John-walking-the Parisian boulevards, John-preparing for an exhibition, John-sleeping-outside, Johneating/writing letters/painting horses-in a café, John-sitting-as a model, John-on the boat, John-in the sea.

My work with narratives is therefore placed within a feminist political project, albeit not that of recovering voices or subjects but of re-imagining the subject of feminism as a nomadic subject, a system of selves grappling with differences and taking up 
subject positions, not in a permanent way, but rather temporarily, as points of departure for nomadic becomings. (Braidotti 1994, 2006)

\section{Charting John's spatiality}

In drawing a cartography of John's spatial constitution, I have followed Doreen Massey's (2005) suggestion for a non-static route of perceiving and analyzing spaces and places. Not surprisingly, given the spatial tactics of the artistic milieus of her era, John's cartography is marked by displacement: indeed she chose to dislocate herself twice: first by leaving Wales to go to London to study at the Slade and then by moving to Paris, never to return home. But what were the conditions of possibility for her deterritorialization? While in the UK John had been harshly marginalized in the bohemian circles of London. In the four years preceding her move to Paris (18881903), she was living in a series of gloomy London flats, one of which was described by her famous brother Augustus as 'a dungeon ... into which no ray of sunlight could ever penetrate' (cited in Langdale 1987, 21). John's obsession with literally living underground in the company of her cat, puzzled and problematised her acquaintances and fellow artists, who labelled her as a recluse. As a young woman trying to pursue her artistic aspirations and live independently, John decided to leave behind the familiar spaces and places of London. As she was writing in her notebook on July $7^{\text {th }}$, 1923:

You are free only when you have left all.

Leave everybody and let them leave you.

Then only will you be without fear. ${ }^{8}$

Escaping fear, John undertook some wild walking adventures in the French countryside, which ultimately took her to Paris. Her move to Paris however, was not to be an intermission of an artist's life as it was the case with many of her contemporaries. ${ }^{9}$ Paris and later Meudon, a nearby suburb, was to become her home for the rest of her life. In tracing John's lines of flight from London to Paris I was particularly intrigued by the long and lively letters that she wrote to her friend Ursula Tyrwhitt about her wild walking adventures in France in the company of Dorelia McNeil, in the summer of 1903 :

We got down at the village when it was dark and went into the inn ... we asked the woman first if she would let us a room and she said she had not got one, which was a lie ... we walked up and down the street singing, to practice singing as sometimes they want us to and then we tried to get a room, but they did not like us in that village, they thought us as mauvais sujets, they asked us two francs for one place which is absurd. We only sleep in on rare occasions, when we work late for then it is rather dangerous to set out, they want to know where we are going to sleep and follow us. When we came back we showed our specimens and began to draw the men who would pose. ${ }^{10}$

The epistolary extract above freezes moments of two young women's experience 'on the road' at the dawn of the twentieth century. Surely, covering one hundred and fifty miles on foot within a month, sleeping rough and singing and drawing in cafés for a 
meal does not exactly resonate with John's biographical representations as a figure of the interior or as a hermit. While on the move, the open spaces of the French countryside and the striated places of the rural French cafés would interact with the desiring bodies of the two young women in ways that would affect and transform both-bodies and spaces. In this light the two young women's imagined journey to Rome would open up heterotopic spaces in the interstices and ruptures of the French countryside they were passing through; their singing and drawing would challenge the hegemony of the patriarchal space of the French tavern, while the enfolding of their bodies would create a holey space sheltering their sleep: 'that night gave us rather a horrid sensation the cold was so frightful ... we lay on each other to feel a little warmer and covered ourselves with our portfolios, but the stones were like ice. ${ }^{, 11}$

John would become attached to this wandering lifestyle and in the bohemian spirit of her era she would defy patterns of a 'bourgeois ordinary life'. As she was writing to Tyrwhitt in a nostalgic mood at the end of 1903 from Toulouse:

We have been here so long now; the time of trudging from village to village seems a long way off. It is very pleasant here, the people gave us plenty of work but I have not done much besides my picture; We shall never get to Rome I'm afraid-it seems further away than it did in England ... Our adventures are not now of such a thrilling nature as we live in a town and have a room and sleep in like any bourgeoisie. ${ }^{12}$

As the letter bitterly foresees, the two young women never got to Rome; moving around without fixed space/time schedules would nevertheless become a recurring pattern of John's spatiality. As she was writing in 1927 to Véra Oumançoff, for whom she developed a passionate attachment later in her life: 'at the moment I am doing some things, which I see in the woods and the meadows and the roads around Meudon. Sometimes I am too tired to come back home in the evening or I'm too far from a station to return and sometimes I don't come home for three or four days. ${ }^{13}$

It seems therefore that throughout her life-long correspondence with her friend and fellow student at the Slade Ursula Tyrwhitt and with her lover Rodin, John was trying to make sense of her self as a woman and as an artist, constantly moving in a complex network wherein the interior, the urban and indeed the rural spaces of modernity blended and blurred in the spatial constitution of the female self. In drawing the cartography of John's spatiality below, I have thus created three planes of smooth and striated spaces: a) the room, the interior and the studio, b) the street, the cafe and the public garden and c) the countryside, the river, and the sea. I have used these planes as heuristic analytic devices, a kind of conceptual spatial configurations to enable the discussion of how heterotopic and holey spaces emerge through the entanglement of bodies and spaces.

\section{Plane one: the room, the interior and the studio}

I have not been posing today, so I washed the floor and everything is brilliant in my room, do come and see my room soon-the floor is of red bricks, and there are tiles in the fireplace and two little grates and all the furniture is brand new, light yellow ... I've got an armoire a glace which is a wardrobe with shelves 
and a glace front, and white lace curtains at the window-yes I am Parisienne and I feel more at home with the French than the English now, I think, at least the English over here. ${ }^{14}$

As this colourful topography in a letter written between 1906 and 1907 to her artist friend Charles McEvoy illustrates, John wrote extensively about her room in her letters. ${ }^{15}$ Her room was creating a milieu for different spatial experiences: it was a place to live, but also to paint, to receive friends, and negotiate work both as a model and as an artist. It is therefore not accidental that John drew beautiful epistolary topographies of her room as the one above and made a series of interiors. ${ }^{16}$

Indeed, John's interiors have created visual images that have challenged the easy equation of the private sphere with the mundane milieu of domesticity. In La Chambre sur la Cour, ${ }^{17}$ painted between 1907 and 1908, John is offering a scene of a woman simply sitting and sewing. While however, this is the figure of the domestic woman par excellence in the company of her cat, the banded hat, hanging on the wicker chair, reminds the viewer of the woman's life outside domesticity. Alicia Foster has noted that John's interiors 'contain signs of life beyond the walls of the rooms' $(1999,49)$ and has particularly commented on how John's interiors create a décor of a woman artist at work through the choice of simple and non-valuable objects: the wicker chair with different pieces of women's clothing and accessories around it, a small pine table, some flowers, the lace curtain, a book left open, a teapot, a newspaper, a pot of paintbrushes on the mantelpiece. ${ }^{18}$ It is through the choice of objects and their spatial arrangement in the planes of her paintings that the domestic as a molar entity is deterritorialized on different planes.

While painting her room and in her room, John never really perceived it as a workplace while living in Paris; in her letters to Tyrwhitt she had expressed her desire for a studio, a necessary place for her identity as a professional artist to be established. Thus on May $6^{\text {th }}, 1910$, she was writing: What I should like to do is to earn enough to take a studio, when you come over, with you and work there. And that must happen within a year at least.' ${ }^{19}$ As a matter of fact in 1910, John moved to Meudon and kept her room in Paris mainly as a studio, which she would visit daily to work. It is quite interesting to note that establishing her Parisian room as a studio occurred at the same time that she was introduced to her American patron, John Quinn, who generously supported her art from around 1914 till his premature death in 1924. The small apartment she took in Meudon would eventually become both her home and her studio when she left the Parisian room in 1918. By that time many things had changed in her life, Rodin had died and it was mainly from this period onwards that John devoted herself to her work, exhibiting both in Paris and in London and firmly establishing herself as an artist.

John's room is therefore often represented both in her letters and paintings as her corner in the world, a place where she could hide and disengage herself from the turbulence of life; a space to dream, to read, to contemplate, to write letters, to cry, to despair and to be happy. It was also an experimental space for her art to develop and sometimes a social space to receive her friends and negotiate work both as a model and as an artist. The boundaries of the room were thus constantly reconfigured through the multiple spatial practices that John would deploy in folding out into the world. John-in-her-room should be perceived as a space-body entanglement that 
would continuously challenge the hegemonic spaces of domesticity. As forcefully emerges from John's letters, the red thread that notably connects the various material and discursive spaces she was entangled with, was her erotic passion for Rodin:

My room is very neat I like it much in the evening when there are shadows in my room ... I like days like these when I don't talk to other people. I am happier when I can think of you in tranquillity and read my books. I was intending to design it in the light of the lamp this evening, but I like it more talking to you know ... I was dreaming of you, last night my Master. ${ }^{20}$

In this extract from an undated letter to Rodin, John's depiction of her room is filled with the shadows of the remains of a very busy day 'outside' and it is indeed very different from the colourful picture of her letter to her friend McEvoy, in the beginning of this section. John used to write to Rodin in the evenings as a way of reflecting upon her thoughts, feelings and deeds at the end of the day. ${ }^{21}$ Her room was the space wherein she felt protected and comfortable to express her passion: 'I made my room and I am waiting for you. ${ }^{22}$

The room and the beloved create here of course an entanglement of striated spaces: indeed John spent ten years of her life arranging her room for Rodin's odd visit and despairing when he would not turn up as expected. But could it really be argued that in waiting for Rodin's visit, Gwen had merely become an abject victim of patriarchy? I think that the spatial ordering of her life as emerging from her letters and paintings was much more diverse and complicated. The fact that she wrote dramatic letters to the beloved - as all lovers do - cannot bound her within a particular model of subjectivity, that of the deserted woman. While 'waiting for the man' John led a very busy life, working, painting and exhibiting. As a matter of fact, eros was a catalytic force in her life. John's love letters should therefore been read within the discursive constraints of the amorous epistolary discourse, ${ }^{23}$ but also as sites of erotic forces intervening in the constitution of the real and the subject herself. But why is the erotic so important?

Drawing on Bergson's philosophy Deleuze (2004) delineates a three-fold structure of time that conditions the living present: contracting the past, archiving the passive present and being driven into unforeseeable futures. In this conceptualization of time, the present makes connections with the pure past-but how? Turning to Proust's notion of involuntary memory, Deleuze suggests that every reminiscence is erotic, connecting us not to the past as former present, but to the past which was never present, the pure past: 'every reminiscence whether of a town or a woman is erotic, it is always Eros, the noumenon, who allows us to penetrate this pure past in itself' $(2004,107)$. I suggest that this philosophical proposition can shed light on the recurrence of the erotic in John's existential spatiality as it is expressed in her letters and paintings. It is through the triggering of the erotic that John's living present is cut off from restrictions of the past, but in simultaneously retaining connections to the pure past - the past that could have been, the love that could have been fulfilled - is ultimately driven into different futures.

Eros as a force is charted here in a cartography of desire: it is not connected to a subject or object; it is a force connecting bodies and destratifying heterosexual segmentarities. Thus, while John spent ten years, fervently in love with Rodin, forces 
of desire saturate her epistolary narratives before and after him; as her famous brother had written for her: 'She was amorous and proud [and] her passions for both men and women were outrageous and irrational' (cited in Tickner 2004, 32). Indeed, erotic desire, amorous encounters with both men and women and intense devotion to and love and care for her cats are constant themes of her letters to her friends and not just Rodin. In this light John's letters carry traces of forces of desire that chart spatial practices within what I have called an amorous epistolary geography. Such practices constantly reconfigure patriarchal boundaries and open up heterotopic and holey spaces not just within John's room but also beyond it, in the Parisian boulevards, cafés and public gardens, as I will further discuss.

\section{Plane two: the street/ the café/ the public garden}

'After my session this evening I took a walk ... I chose dark streets, since I am happier when I walk in dark streets; I can think in tranquility, looking at the sky, when there is no noise and no much light. ${ }^{24}$ As this extract from an undated letter shows, John's lived spaces can be charted well beyond her room. She lived in and moved through a variety of public spaces, painted them and wrote about them in her letters. There is nothing surprising here of course; feminist theorists have well documented and discussed the possibilities and constraints of women's mobility in the urban and rural spaces of modernity. ${ }^{25}$

In her analysis of Paris, Wilson has noted that 'women formed an essential element of the crowds in the streets' $(1991,61)$ and 'going out' and sitting in cafés was part of the Parisian life-style anyway, given the cramped conditions of housing even for the middle classes. Wilson's analysis has focused on the pleasure element of the Parisian milieu and the sexualization of the city. She has particularly noted that in the belle époque period (1890-1910) - more or less the years that John settled down in Parisforbidden sexualities and gay subcultures became more visible in the urban milieu. John's letters about her experiences of moving through public spaces do not reflect so much an image of Paris as 'a capital of pleasure, excitement and consumption' (47); they rather portray the difficulties of a young woman artist to survive, although they do depict Paris as an intensely sexualised city, as I will further discuss.

Going out and walking in the streets takes up several meanings in John's epistolary discourse: it is a cluster of spatial practices, often linked to financial anxieties. 'I looked for a job this week, but didn't find any. I saw very few people while I knocked on many, many ateliers', ${ }^{26}$ she was writing in a letter at around 1906 . On other occasions she would walk for hours to get the right frame for a picture, or find out what would be the most secure way to send a picture for an exhibition. John was thus one of those women who walked the streets of Paris, without necessarily being a streetwalker or a flâneuse, a theme that has fuelled heated discussions, as I have already noted. ${ }^{27}$

Given the financial difficulties that John would face as a single woman artist in Paris, cafés or restaurants would be transformed in places for reading and letter-writing. The following letter written on the printed letterhead of a Montparnasse taverne in February 1910, is a good example of how public places could be transformed into intimate spaces within John's daily practices: 
Taverne de la Brasserie Dumesnil Frères, 73 Boulevard, Montparnasse, Paris.

Dearest Ursula,

Isn't this a dreadful piece of paper? It is so cold in my room and I haven't the energy to light the fire so I've come here to write to you, there is a band here and a lot of startling ladies amongst the men but I have books and writing paper all over the table so they think me only a mad Anglaise. ${ }^{28}$

While John's practice of writing letters has opened up heterotopic spaces within the dominant space of the Parisian tavern, clearly such transformations were only ephemeral and fragile: public spaces would not always be perceived as friendly and welcoming for a single woman. Indeed John has frequently written about her frustration of being in public places as in the following undated letter, where she recounts her experiences of painting tram horses in a Parisian café:

I have just returned from a café where I was drawing horses. A man dressed as a dandy came near and started talking to me. I had gone there to draw and not to talk to him, so I told him that I could not understand French. To my surprise instead of going away on hearing that, he sat next to me, ordered a coffee and started talking to me ... I could not understand what he was saying because I was focusing on my drawing but I could follow some of his words. In the end, people would stop and look at us and I was feeling very agitated and could not concentrate. I could hear him saying that he was a journalist and that he was very annoyed with the conductors who were staring and laughing at us. I was designing the ears of a horse and he was saying that when I would design the conductors I should make them with donkey ears ... I could not help laughing ... but still I was very annoyed and I left since so many people were staring. ${ }^{29}$

There is nothing unusual with the situation recounted above: a single woman being harassed while drawing in a café. What is interesting however in John's narrative is the ambiguous way that the story unfolds, different voices and perspectives merge and the overall effect finally becomes both funny and unbearable. Bu what can this particular narrative of the café encounter convey about who John is and how she feels? What I suggest is that the letter about drawing tram horses in a Parisian café is a narrative of the paradoxical events emerging in a woman's lived experiences of the urban spaces of modernity - being in the crowd but not part of it. The letter carries signs of John's nomadic passages: an artist in a café, a harassed woman, a woman who laughs, a woman who loves; it further inscribes some of the tactics that John would deploy in surviving the urban spaces of modernity: laughing away, employing the discourse of the foreigner-I don't speak French - but always leaving in the end. These tactics were enabling, but not always successful. Indeed John's many letters about being harassed while in public spaces, compose a thoroughly sexualized image of the city and could be read within the discursive framework in which Wilson has placed her discussion of Paris as 'the crucible both of sexual freedom and of political revolution' (1991, 48). Read within a range of constraints and limitations, John's letters nevertheless unveil the complex ways that she would experience space in terms of pure intensities rather than prescribed movements in between gendered divided spheres. 
John's life cannot therefore be firmly placed in either 'compartment' of the private/public, inside/outside model. Nor can it be argued that despite her eagerness to access the public sphere, it was actually her room that she really wanted to be in (Wolff 1994, 118). What I have found intriguing in tracing narrative lines of her spatial practices both in her letters and paintings, is the interchange of dominant, heterotopic and holey spaces in a kind of a cyclical recurrence, a Nietzschean eternal return of her 'will to solitude' (Tamboukou 2010b, 16). In this light the city gardens often emerge as holey spaces sheltering her sleep. As she was writing to Tyrwhitt in July 1904:

We have been out for a walk it is quite late, the sky is a deep blue with some great clouds, the Luxembourg gardens looked so beautiful with no soul there so quiet and peaceful $\&$ the trees are so beautiful down the streets casually lit up as a lamp. I sometimes sleep in the gardens in a little copse of trees. ${ }^{30}$

The Luxembourg gardens, a short walk from all the places John used to live in the area of Montparnasse, were indeed a frequent destination. There were different occasions on which John would spend time in the gardens. Sometimes it was because she could not stand the unbearable heaviness of waiting for Rodin. At these moments, the room she loved so much turned into a suffocating place she had to get away from. As she was writing to Rodin: 'I desire you so much my Master that I can't take pleasure in my room now', ${ }^{31}$ and in a different letter: 'I am now going to the Luxembourg gardens my Master ... In the gardens I always think of you in tranquillity and I keep the thoughts that annoy me at a distance'. ${ }^{32}$

The Luxembourg gardens would thus recreate the calm atmosphere of her room and paradoxically enough would be reconfigured as an outer space of intimacy in which she would live her love and passion for Rodin minus the intrusive anticipation of his visit. John would often write letters in the gardens, as recounted in the letter below to Tyrwhitt on September $30^{\text {th }}$, 1909: 'I am writing in the Luxembourg gardens, it is so lovely here, but quite autumn'. ${ }^{33}$

While working in Paris at the archives of the Rodin Museum, I followed John's steps from the various addresses to the Parisian boulevards and the Luxembourg gardens. It was a strange experience as I was attempting to recreate existential paths within different space/time conjunctions. As Williams has noted, 'each present, each life is connected to all others but to greater and lesser degrees of contraction' $(2003,97)$. In this light Deleuze has suggested that 'one life may replay another at a different level' (cited in Williams 2003, 93). Finding myself replaying John's paths a hundred years later, I was really struck and perplexed by the power of her strange familiarity with fin-de-siècle urban spaces. How could a public garden be transformed into a holey space sheltering a young woman's sleep? As has been persuasively discussed in a rich body of feminist literature, spatial refrains cannot become intelligible within the long held private/public dichotomy. ${ }^{34}$ Indeed, John's intimate practices would constantly challenge the patriarchal urban spaces of modernity: John-walking-in the Parisian boulevards, John-writing letters-in a café or John-sleeping-in the Luxembourg gardens create space/bodies entanglements that keep redrawing the boundaries of what a woman could be or do, opening up heterotopic and holey spaces within and beyond the city, as I will further show. 
John's love and admiration for Nature emerges as a recurring theme in her personal writings since the time of living in London. Indeed, her letters unravel complex interrelations between gender, aesthetics and spatial relations (see, Mills 2000). In search of this love for Nature, John would often set out for excursions in the surrounding countryside, taking the boat down the Seine, walking, painting, reading and again sleeping in the woods when tired. As she was writing to Rodin: 'I did not sleep well tonight either and after having tried to draw, I finished my housework, took my book and went out to the country ... now I feel better since I have been out for a long walk in the country. It is strange how walking for long relieves my heart! ${ }^{35}$

Usually on her own but sometimes in the company of other women artists, John went out and around, constantly reconfiguring the boundaries of what her body could do. A letter to her friend McNeil, written in May 1905 gives a colourful picture of these outings: 'It is very hot here now. I went with M. Flodin ${ }^{36}$ to Surennes yesterday, we slept under the trees and drew each other and came home at night when all the river was illuminated with lanterns and windows. ${ }^{37}$

John deeply enjoyed her days out in the countryside surrounding Paris despite the risks that this love involved. Indeed she has written extensively about dangerous encounters during her walking adventures in the woods surrounding Paris. The spatial tactics of walking in the city would be redeployed in the rural spaces, as recounted in her following undated letter to Rodin:

The place I most like going is near a lake, there is much greenery there, big spaces and groups of very big trees. I did not go far away from the path, for the sake of security and so I remained at a spot where people could see me. (This is because there are many men who always go around, but if you are in the open, they don't dare come near you). As for me, I ate first and then I slept. $^{38}$

Despite the cautionary tone of the letter above, John would often overstep security boundaries, finding herself in confrontation with men harassing her. As her biographer has noted, sometimes her practices of resistance would verge to the point of criminal assault. (Chitty 1981, 105) She would eventually override all difficulties however, given her love and passion for being outside. During these outings that comprise a big part of her daily routine, the boat as a floating heterotopic space, often seems to create conditions for solitary reflection:

I did not pose at all today ... I took my book of Aeschylus and I read it on the boat to Surennes, I walked a little in the forest, it was so sweet and calm there and in returning I was reading my book inside the boat since it was cold and dark on the deck ... There were great shadows there ... there are shadows in my room now. ${ }^{39}$

The smooth space of the water seems to sooth John's tormented self; as her biographer has noted, the sea was one of her greatest life passions. Indeed, since the days of her childhood in Wales, John used to search for secluded and wild spots where 'she could bathe naked off the rocks and swim far out to sea, excited by the 
fear that she might not be able to get back.' (Chitty 1981, 30) John had expressed this great passion for the sea in her letters long before moving to Paris. As she was writing to her friend Michel Salaman in the spring of 1899, while staying with her brother Augustus and his wife Ida in Liverpool:

I bathe in a natural bath, three miles away, the rocks are treacherous there, and the sea unfathomable. My bath is so deep I cannot dive to the bottom, and I can swim in it- but there is no delicious danger about it, so yesterday I sat on the edge of the rock to see what would happen- and a great wave came and rolled me over and over - which was humiliating and very painful and then it washed me out to sea and that was terrifying-but I washed up again. ${ }^{40}$

In the last years of the First World War and while residing in a deserted mansion in Brittany where she could work in peace, John would take daily walks to the nearby beach, often diving 'into the crashing breakers of the Grève des Vallèes'. (Chitty 1981, 152) Indeed John was attracted by the openness and fluidity of the sea, which becomes a recurrent theme in the cartography of her spatiality and a constant reference of her dreams and her epistolary narratives.

\section{Epistolary Geographies, Heterotopic and Holey Spaces, Nomadic Becomings}

As I have discussed in this paper, John's letters carry traces of everyday spatial practices and lines of flight from striated spaces. There are many and different spaces within which John's experiences fold, refold and unfold, but her letters hold these differences together, not as oppositions but as multiplicities: striated - and - smooth spaces, inside - and - outside, public - and - private, solitude - and - communication. Eros as a force of life has emerged as a red thread weaving together singularities, multiplicities and differences and holding together John's selves in a space/time rhythm that although alternating between slowness and speed does not completely derail her from the plane of life, a danger that Deleuze and Guattari have identified in their analyses of lines of flight. $(1988,229)$

Clearly there were many possibilities available for John shaped by the social and cultural conditions of her geographies and times. As a student of the well-known Slade, she was educated to become 'the new woman' of modernity par excellence. The artistic bohemian circles of London and later Paris were supposedly opening more opportunities for her to realize her existence, attain freedom and fulfill her aspirations in the world of art. However John did not follow prescribed paths: girl goes to the Slade, trains as an artist, starts exhibiting, lives in the bohemian circles of London, gets married or not, goes on working or gives it up to support her artist partner, dies at giving birth. ${ }^{41}$ John's space/time blocks were disrupted: she became a minoritarian subject even amongst the margins of the bohemian circles in London, went off travelling, ended up in Paris, had to work as a model to support herself and her art, met Rodin, fell in love, her lines of flight became reterritorialized within Rodin's circle, but once again she became a minoritarian figure within the Parisian artists' colony. John abandoned common sense for visceral experiences of unlimited passion and uncompromised solitude: she painted, wrote letters to her lover and friends and looked after her cat(s). In this light her life unfolded against the rhythm of a specific set of occurrences structuring Woman's space/time: she lived out of order, 
as a perpetual stranger/other of the urban and rural spaces of modernity. Indeed, John followed the dream of becoming an artist by following lines of flight, unfolding her bodily forces in a multiplicity of spaces and making connections with other bodies, human and non-human. As marks left behind nomadic passages of striated and smooth spaces, John's letters and paintings express the complex ways that she experienced space in terms of pure intensities and chart a unique map of heterotopic and holey spaces within which she kept redistributing and consequently reinventing herself and her relation to the world.

What I have shown in charting John's spatiality, is that the spaces of her actualitythe room, the street, the café, the public gardens, the river, the sea and the countryside - constitute an entanglement of striated and smooth spaces that are continuously traversed, opening up heterotopic and holey spaces, 'tents for the nomad'. Heavily invested with images, discourses, emotions and affects, this spatial entanglement creates conditions of possibility for rhizomatic connections ${ }^{42}$ to be made between its disparate components as well as with components of other spaces, real and imagined. As John lived in and moved through this network of heterotopic and holey spaces, different sets of spatial relations and practices were enacted that would occasionally 'suspend, neutralize or reverse' the patriarchal structures underpinning the conception of these spaces: the room, being the space of a single woman and thus not related to the demands of any type of domestic economy would trigger and accommodate the creativity of the artist and shelter passionate connections with other bodies; the street, the café, and the public gardens, normally perceived as inimical territories for single women, would make rhizomatic connections with the intimacy and tranquility of the room and offer shelter to an impatient lover, a young woman who could not afford or manage a fire in her room, an artist who loved and admired nature.

In this light, spaces and bodies do not pre-exist as autonomous or independent entities: they rather emerge through the connections they make: bodily movements and the materiality of spaces form affective entanglements in a continuous process of transpositions and becomings. Thus the room can never be stabilized as a Woolfian space of creativity, a patriarchal domestic trap, a heterosexual nest or a shelter of a woman in crisis: it is always, already something else - a space that keeps changing, a labile, transient space. In a parallel line the Parisian cafés or taverns are not predefined spaces where a woman can mingle with the crowd, write a letter, paint tram horses or just eat: there are heterogeneous components and functions, sometimes contradictory, other times complementary, but again the public space of a café or a tavern is already something more, less or different from its conception. What the concepts of heterotopias and holey spaces therefore illuminate in the analysis, is that the configuration of John's spatiality can never close or become 'complete'; it is only her movements in between different and differing spaces that can be charted. John's spatial stories carry signs of lines of flight, inscribing other ways of becoming a woman and an artist, making cartographies that destabilize and challenge, static conceptualizations of spaces and subjectivities.

\section{Archival sources}

National Library of Wales, Archives, Gwen John's papers (NLW MS)

Rodin Museum, Marie Gwendolen John's Boxes (MR/MGJ) 


\section{References}

Braidotti, R. 1994. Nomadic Subjects. New York: Columbia University Press.

Braidotti, R. 2006. Transpositions: on nomadic ethics, Cambridge: Polity Press.

Deleuze, G. 2000. Proust and the Signs. Minneapolis: University of Minnesota Press.

Deleuze, G. 2004. Difference and Repetition. London: Continuum.

Deleuze, G. and Guattari, F. 1988 A Thousand Plateaus: Capitalism and Schizophrenia. London: The Athlone Press.

Foster, A. 1999. Gwen John. London: Tate Gallery publishing.

Foucault, M. 1988. Technologies of the Self. In Technologies of the Self, ed. L, H. Martin, H. Gutman, P. H. Hutton, 16-49. London: Tavistock.

Foucault, M. 1990. The History of Sexuality, An Introduction, vol. 1, Harmondsworth: Penguin.

Foucault, M. 1998. Different Spaces. In Michel Foucault, Aesthetics, Method and Epistemology, the essential works of Michel Foucault, 1954-1984, vol. II, ed. P. Rabinow, 175-185. Harmondsworth: Penguin.

Hetherington K. 1997. The Badlands of Modernity: Heterotopia and Social Ordering. London: Routledge.

Langdale, C. 1987. Gwen John, With a Catalogue Raisonné of the Paintings and a Selection of the Drawings. New Haven and London: Yale University Press.

Langdale, C. and Jenkins, D. 1985. Gwen John: An Interior Life. New York: Rizzoli.

Lloyd-Morgan, C. 2004. Gwen John: Letters and Notebooks. London: Tate Publishing in association with the National Library of Wales.

Lorraine, Tamsin. 2005. "Ahab and Becoming-Whale: The Nomadic Subject in Smooth Space”. In: Ian Buchanan and Gregg Lambert, Eds. Deleuze and Space. Edinburgh: Edinburgh University Press, 159-175.

Massey, D. 2005. For Space. London: Sage.

Massumi, B. 1993. A User's Guide to Capitalism and Schizophrenia. Cambridge MA: The MIT Press.

Nesci, C. 2001. Flora Tristan's Urban Odyssey: Notes on the Missing Flâneuse and Her City. In Journal of Urban History, 27, 709-722.

Parsons, D., L. 2000. Streetwalking the Metropolis: Women, the City and modernity. Oxford: Oxford University Press.

Perry, G. 1995. Women Artists and the Parisian Avant-Garde. Manchester: Manchester University Press.

Pollock, G. 1988. Vision and Difference. London: Routledge.

Probyn, E. 1993. Sexing the Self: Gendered Positions in Cultural Studies. London: Routledge.

Probyn, E. 1996. Outside Belongings. London: Routledge.

Ryan, J. 1994. Women, Modernity and the City. Theory, Culture and Society, 11: 3563.

Saldanha, A. 2008. Heterotopia and Structuralism. Environment and Planning, 40 (9), 2080-2096.

Smith, S. and Watson, J. 2001. Reading Autobiography : A Guide for Interpreting Life Narratives. Minneapolis: University of Minnesota Press.

Tamboukou, M. 2010a. In the fold between power and desire: Women artists' narratives. Newcastle upon Tyne: Cambridge Scholars Publishing.

. 2010b. Nomadic narratives, visual forces: Gwen John's letters and paintings.

New York: Peter Lang. 
Thomas, A. 1994. Portraits of Women: Gwen John and her Forgotten Contemporaries. Cambridge: Polity Press.

Tickner, L. 2004. "Augustus's Sister": Gwen John: Wholeness, Harmony and Radiance. In Gwen John and Augustus John, ed. D.F. Jenkins and C. Stephens, 29-45. London: Tate Publishing.

Williams, J. 2003. Gilles Deleuze's Difference and Repetition: a critical introduction and guide' Edinburgh: Edinburgh University Press.

Wilson, E. 1991. The Sphinx in the City: urban life, the control of disorder, and women. Berkeley: University of California Press.

Wolff, J. 1994. The artist and the flâneur: Rodin, Rilke and Gwen John in Paris. In The Flâneur, ed. K. Tester, 111-137. London:Routledge.

${ }^{1}$ MR/MGJ, B.J5, undated letters, citing persons.

${ }^{2}$ See author.

${ }^{3}$ See Massey 2005 for an analysis of the fluidity of space

${ }^{4}$ There is indeed a growing literature amongst critical geographers, cultural theorists and sociologists, drawing on the concept of heterotopia. See Saldanha 2008 for a critical overview of this literature and an interesting critique of the concept itself.

${ }^{5}$ See Smith and Watson, 2001 for an overview and discussion of this literature.

${ }^{6} \mathrm{John}$ was passionately attached to her cats and lived surrounded by them throughout her life. For a discussion of her relationship to cats, see author.

${ }^{7}$ For a discussion and analysis of the entirety of John's correspondence, see author.

${ }^{8}$ Lloyd-Morgan 2004, 130.

${ }^{9}$ As pointed out in Gill Perry's study of women artists in Paris in the early twentieth century, 'there were [...] many women artists from Europe and America who were coming to Paris for shorter periods to work and/or study and exhibit [since] Paris had become an undisputed international centre with a seemingly magnetic appeal' $(1995,16)$.

${ }^{10}$ NLW, MS 21468D, ff.3-4.

${ }^{11}$ Ibid., f. 6.

${ }^{12}$ Ibid., ff. 7-8.

${ }^{13}$ Lloyd-Morgan 2004, 157.

${ }^{14}$ Lloyd-Morgan 2004, 40.

${ }^{15}$ John lived in a series of independent studio apartments. When she first settled down in Paris, she took a room at 7 Rue St-Placide, which was rather dark and cold and following Rodin's encouragement and financial support, she moved to 87 Rue du Cherche-Midi, in 1907, the room she loved and painted most. In 1909 she moved again to 6 Rue De l'Ouest till 1910 when she took the top flat at 29 Rue Terre-Neuve in Meudon, keeping the Parisian room as a flat till 1918. In 1929 she bought a plot at 8 Rue Babie, Meudon, but only moved there in 1936, just three years before she died. All her rooms in Paris were in blocks of flats in the area of Montparnasse.

${ }^{16}$ See, Langdale, 1987: La Chambre sur La Cour, pl. 47, cat. no. 15, 34; A Corner of the Artist's Room in Paris, pl. 183, cat. no. 16, 138; A Corner of the Artist's Room in Paris with Open Window, pl. 32, cat. no. 17, 30; The Artist in her Room in Paris, pl. 33, cat. no. 18, 30; A Lady Reading, pl. 53, cat. no. 24, 38; Girl Reading at the Window, pl. 54, cat. no. 25, 38; Interior, pl. 84, cat. no.49, 61; The Brown Teapot, pl. 203, cat. no. 50, 150; The teapot (Interior: Second Version), pl. 204, cat. no. 51, 150; Interior, Rue Terre Neuve, pl. 93, cat. no. 226, 64; Interior Rue Terre Neuve, pl. 115, cat. no. 123, 75. ${ }^{17}$ Langdale, 1987, 34, pl.47, no. 15

${ }^{18}$ Gwen John's paintings can be viewed on different websites, see the Bridgeman Art Library for a comprehensive collection http://www.bridgemanart.com/search.aspx?key=Gwen\%20John\& filter=CBPOIHV\#top

${ }^{19}$ NLW MS 21468D, f. 44.

${ }^{20} \mathrm{MR} / \mathrm{MGJ} / \mathrm{B} . J 3$.

${ }^{21}$ During the ten years se was in love with Rodin, (1904-1914) John sent him around two thousand letters, but she continued to write to him sporadically till his death in 1917. There were only sixty-nine letters from Rodin in the Archives, mostly short notes arranging meetings and encouraging her to look after her health.

${ }^{22} \mathrm{MR} / \mathrm{MGJ}, \mathrm{B} . J 3$.

${ }^{23}$ See author for a discussion of Johns amorous epistolary discourse.

${ }^{24} \mathrm{MR} / \mathrm{MGJ}, \mathrm{B} . J 4$. 
${ }^{25}$ For feminist discussion of women artists' relation to the urban spaces, see amongst others, Parkhurst,1994; Parsons, 2000; Perry, 1995; Pollock, 1988; Ryan, 1994; Wilson, 1991; Wolff, 1994.

${ }^{26} \mathrm{MR} / \mathrm{MGJ} / \mathrm{B} . J 4$, letters to Julie 1906-1907.

${ }^{27}$ See Catherine Nasci, 2001 for an interesting discussion of the fin-de-siècle woman who walks in the streets, not necessarily as a flâneuse.

${ }^{28}$ NLW MS 21468D, ff.38-40.

${ }^{29} \mathrm{MR} / \mathrm{MGJ} / \mathrm{B} . J 4$, undated.

${ }^{30}$ Ibid., f. 14.

${ }_{31}^{31} \mathrm{MR} / \mathrm{MGJ}, \mathrm{B} . J 3$, undated letters without name or place.

${ }^{32}$ Ibid.

${ }^{33}$ NLW MS 21468D, ff.36-37.

${ }^{34}$ For an overview and appreciation of this literature, see Scott and Keat, 2004.

${ }_{35}^{35} \mathrm{MR} / \mathrm{MGJ} / \mathrm{B} . J 3$, undated letters without name or address.

${ }^{36}$ Hilda Flodin was a Finish sculptress from Rodin's circle.

${ }^{37}$ Lloyd-Morgan 2004, 38.

${ }_{38}^{38} \mathrm{MR} / \mathrm{MGJ} / \mathrm{B} . J 3$, undated letters without place or name.

${ }^{39} \mathrm{MR} / \mathrm{MGJ} / \mathrm{B} . J 3$.

${ }^{40}$ Lloyd-Morgan 2004, 21.

${ }^{41}$ Indeed, these were more or less the regular events structuring the life of many of her contemporaries, See Thomas, 1994.

${ }^{42}$ The rhizome is an important concept in Deleuze and Guattari's geophilosophy (1988) configuring horizontal and surface relations between disparate elements and unsettling fixed structures and positions. 